\title{
Least Cost Diet for Children Two to Three Years in Malaysia Using Linear Programming Approach
}

\author{
Nor Hayati Shafii ${ }^{*}$, Rohana Alias ${ }^{2}$, Noradilla Radzuan ${ }^{3}$ \\ ${ }^{1,2,3}$ Faculty of Computer and Mathematical Sciences, Universiti Teknologi MARA Perlis Branch, \\ Malaysia \\ Corresponding author: *norhayatishafii@perlis.uitm.edu.my
}

Received Date: 30 August 2018

Accepted Date: 12 November 2018

\begin{abstract}
The early period of life, namely from birth to two years of age is critical for the promotion of optimal growth, brain development as well as health and behavioural development. Thus, attaining the daily required nutrition during this stage of life is very crucial since nutrition is strongly associated with a child's development at a very young age. It is a major challenge for Malaysians to ensure children get a balanced diet, especially children from families of low socioeconomic status. As reported in the Edge Weekly, the review found that $24.9 \%$ or nearly one in four children in Malaysia experienced moderate or severe food insecurity due to financial constraints. In this study, a linear programming diet model is used to determine an affordable cheapest food basket that satisfies the daily recommended nutritional requirements for children between two to three years old in Malaysia. POM-QM for Windows Version 5.2 by Howard J. Weiss is used. Initial finding shows that the average costs are RM2.69. This food basket consists of 474g of eggs, $55 \mathrm{~g}$ of tofu, $29 \mathrm{~g}$ of papaya, $5 \mathrm{~g}$ of spinach and $201 \mathrm{~g}$ of potato. With this food basket and estimated food expenditure, parents can save for $40 \%$ of their child's daily food expenditure.
\end{abstract}

Keywords: Food Items, Linear Programming Model, Low Cost, Nutrition, Optimization

\section{INTRODUCTION}

Malnutrition is associated with about half of all child deaths worldwide (Eunice et al., 2014). Possible explanations for this as addressed by Schönfeldt et al. (2010) are inefficient education on healthy eating habits and lack of ability to gain the necessary education due to economic constraints.

Socioeconomic background is the main factor for parents ability to buy food with sufficient nutrients or otherwise ("WHO Global Database on Child Growth and Malnutrition 14," 2011). In Malaysia, the prevalence of underweight and stunting persist among young children from poor rural areas (Khor \& Sharif, 2003). According to Temim et al. (2010), the problem could be addressed by initiating low cost changes in the health system that would make the entire sector more responsive to the targeted people's requirements.

Linear programming has been utilised in various applications involving diet related problems. Okubo et al., (2015) has used linear programming to determine the pattern of food intake in fulfilling the recommendation of nutrient by Dietary Reference Intake (DRIs). Numerous researches have been done with different purposes such as by Briend et al., (2008) and Van der Merwe et al., (2014). 


\section{LP MODEL FORMULATION}

This study uses linear programming approach i.e Simplex Method to determine the minimum food budget that satisfies the nutritional requirements for Malaysian children aged two to three years old. The nutrient content was derived from SELF Nutrition Data of Standard Tables Food Composition at nutritiondata.self.com. The Malaysian Dietary Guidelines for Children and Adolescents Summary was used to obtain the caloric, nutrient requirements, and Malaysian favourite food items.

The suggestion by Ministry of Health (2013) was used to identify the food items in the food basket. The collection of food prices was carried out at Giant Hypermarket Kangar on March 26, 2017, and the prices were normal prices without promotion or discount.

Objective function: Minimise cost

where,

$$
\mathrm{Z}=\sum_{j=1}^{15} c_{j} X_{j}
$$

$X_{j}=$ The quantity $(100 \mathrm{~g})$ of the food item $j, c_{j}=$ The cost of $(100 \mathrm{~g})$ of food item $j$.

The food items are milk $\left(X_{1}\right)$, yoghurt-plain $\left(X_{2}\right), \operatorname{chicken}\left(X_{3}\right), \operatorname{egg}\left(X_{4}\right), \operatorname{mackerel}\left(X_{5}\right), \operatorname{tofu}\left(X_{6}\right)$, banana $\left(X_{7}\right)$, papaya $\left(X_{8}\right)$, carrot $\left(X_{9}\right)$, spinach $\left(X_{10}\right)$, white rice $\left(X_{11}\right)$, white bread $\left(X_{12}\right)$, potato $\left(X_{13}\right)$, plain biscuits $\left(X_{14}\right)$, and noodles $\left(X_{15}\right)$.

The above objective function is subjected to the constraints:

where,

$$
\sum_{j=1}^{15} A_{i j} X_{i j} \geq B_{i} \quad ; \quad X_{j} \geq 0
$$

$A_{i j}=$ The amount of nutrient $i$ in food item $j$, and $B_{i}=$ Minimum daily requirement of nutrient $i$.

The constraints are Carbohydrates $\left(\mathrm{C}_{x} \mathrm{H}_{y} \mathrm{O}_{z}\right)$, calcium $(\mathrm{Ca})$, iron $(\mathrm{Fe})$, magnesium $(\mathrm{Mg})$, phosphorus $(\mathrm{P})$, potassium (K), sodium (Na), vitamin A (Vit.A), vitamin C (Vit.C), vitamin E (Vit.E), vitamin K (Vit.K), energy, protein, and fats (Refer to Table 1).

\section{Table 1: Price and Nutritional Content of 100 grams of Food Items}




\begin{tabular}{|c|c|c|c|c|c|c|c|c|c|c|c|c|c|c|c|}
\hline & $\begin{array}{c}\text { Price } \\
(\mathrm{RM})\end{array}$ & $\begin{array}{c}\text { Energy } \\
(\mathrm{kJ})\end{array}$ & $\begin{array}{c}\text { CxHyOz } \\
(\mathrm{g})\end{array}$ & $\begin{array}{c}\text { Fats } \\
(\mathrm{g})\end{array}$ & $\begin{array}{c}\text { Protein } \\
(\mathrm{g})\end{array}$ & $\begin{array}{c}\text { Vit.A } \\
(\mathrm{mg})\end{array}$ & $\begin{array}{c}\text { Vit.C } \\
(\mathrm{mg})\end{array}$ & $\begin{array}{c}\text { Vit.E } \\
(\mathrm{mg})\end{array}$ & $\begin{array}{c}\text { Vit.K } \\
(\mathrm{mcg})\end{array}$ & $\begin{array}{c}\mathrm{Ca} \\
(\mathrm{mg})\end{array}$ & $\begin{array}{c}\mathrm{Fe} \\
(\mathrm{mg})\end{array}$ & $\begin{array}{c}\mathrm{Mg} \\
(\mathrm{mg})\end{array}$ & $\begin{array}{c}\mathrm{P} \\
(\mathrm{mg})\end{array}$ & $\begin{array}{c}\mathrm{K} \\
(\mathrm{mg})\end{array}$ & $\begin{array}{c}\mathrm{Na} \\
(\mathrm{mg})\end{array}$ \\
\hline Milk & 0.5 & 176 & 5.2 & 1 & 3.4 & 58.8 & 0 & 0 & 0.1 & 119 & 0 & 11 & 95 & 150 & 44 \\
\hline Yoghurt & 0.78 & 255 & 4.7 & 3.3 & 3.5 & 29.7 & 0.5 & 0.1 & 0.2 & 121 & 0.1 & 12 & 95 & 155 & 46 \\
\hline Chicken & 0.72 & 691 & 0 & 3.6 & 31 & 6.3 & 0 & 0.3 & 2.8 & 15 & 1 & 29 & 228 & 256 & 74 \\
\hline Egg & 0.33 & 821 & 0.9 & 15.3 & 13.6 & 218.7 & 0 & 1.2 & 0.3 & 59 & 2 & 13 & 208 & 147 & 204 \\
\hline Mackere1 & 0.96 & 1097 & 0 & 17.8 & 23.9 & 54 & 0.4 & 0 & 0 & 15 & 1.6 & 97 & 278 & 401 & 83 \\
\hline Tofu & 0.3 & 607 & 4.3 & 8.7 & 15.8 & 49.8 & 0.2 & 0 & 0 & 683 & 2.7 & 58 & 190 & 237 & 14 \\
\hline Banana & 0.37 & 373 & 22.8 & 0.3 & 1.1 & 19.2 & 8.7 & 0.1 & 0.5 & 5 & 0.3 & 27 & 22 & 358 & 1 \\
\hline Papaya & 0.28 & 163 & 9.8 & 0.1 & 0.6 & 328.2 & 61.8 & 0.7 & 2.6 & 24 & 0.1 & 10 & 5 & 257 & 3 \\
\hline Carrot & 0.3 & 147 & 8.2 & 0.1 & 0.6 & 4137 & 2.6 & 0 & 9.4 & 32 & 0.9 & 10 & 28 & 237 & 78 \\
\hline Spinach & 1.5 & 96.3 & 3.7 & 0.3 & 3 & 3144 & 9.8 & 2.1 & 494 & 136 & 3.6 & 87 & 56 & 466 & 70 \\
\hline Rice & 0.23 & 544 & 28.6 & 0.2 & 2.4 & 0 & 0 & 0 & 0 & 3 & 1.5 & 13 & 37 & 29 & 0 \\
\hline Bread & 0.6 & 1227 & 54.4 & 4 & 9 & 0 & 0 & 0.2 & 3.4 & 119 & 3.3 & 26 & 103 & 131 & 592 \\
\hline Potato & 0.4 & 389 & 21.2 & 0.1 & 2.5 & 3 & 9.6 & 0 & 2 & 15 & 1.1 & 28 & 70 & 535 & 10 \\
\hline Biscuits & 1.06 & 1528 & 48.5 & 16.5 & 6.2 & 0.6 & 0 & 1.3 & 4.1 & 49 & 3.3 & 17 & 430 & 224 & 1052 \\
\hline Noodles & 0.22 & 1608 & 71.3 & 4.4 & 14.2 & 18.6 & 0 & 0.4 & 0.5 & 35 & 4 & 58 & 241 & 244 & 21 \\
\hline & & & & & & & & & & & & $\mathrm{X}$ & $\mathrm{X}$ & $\mathrm{X}$ & $\mathrm{X}$ \\
Constraint & & $\mathrm{X} \geq 1000$ & $\mathrm{X} \geq 22$ & $\mathrm{X} \geq 5$ & $\mathrm{X} \geq 12$ & $\mathrm{X} \geq 300$ & $\mathrm{X}$ & $\mathrm{X} \geq 6$ & $\mathrm{X}$ & $\mathrm{X}$ & $\mathrm{X} \geq 7$ & $\geq 65$ & $\geq 380$ & $\geq 2000$ & $\geq 1000$ \\
& & & & & & & & & 230 & $\geq 700$ & & & \\
\hline
\end{tabular}

Prior to using POM-QM software to obtain the optimal solution, the inequality constraints were converted to equality constraints. This was done by introducing the slack and artificial variables. Specifically, in this study all the constraints contain more than inequality $(\geq)$.

For example, the energy constraint is shown in equation (1).

$$
\left(\begin{array}{c}
176 X_{1}+255 X_{2}+691 X_{3}+821 X_{4}+1097 X_{5}+ \\
607 X_{6}+373 X_{7}+163 X_{8}+147 X_{9}+96.3 X_{10} \\
+544 X_{11}+1227 X_{12}+389 X_{13}+1528 X_{14}+1608 X_{15} \geq 1000 \mathrm{~kJ}
\end{array}\right)
$$

Subtracting the surplus $S_{1}$ and adding the artificial variables $A_{1}$ in equation (1) results in equation (2).

$$
\begin{aligned}
176 X_{1}+255 X_{2}+691 X_{3}+ & 821 X_{4}+1097 X_{5}+ \\
& 607 X_{6}+373 X_{7}+163 X_{8}+147 X_{9}+96.3 X_{10} \\
& +544 X_{11}+1227 X_{12}+389 X_{13}+1528 X_{14}+
\end{aligned}
$$

\section{RESULTS AND DISCUSSION}

Table 2, 3 and 4 show the linear programming results. The result shows that RM2.68 is the minimum

\begin{tabular}{|c|c|c|c|c|c|c|c|c|c|c|c|c|c|c|c|}
\hline Milk & Yogurt & Chicken & Egg & Mackerel & Tofu & Banana & Papaya & Carrot & Spinach & Rice & Bread & Potato & Biscuits & Noodles & RHS \\
\hline
\end{tabular}
amount that parents need to spend daily on food for children of two to three years old, to meet their necessary nutritional requirements. The food basket must consist of $4.69 \mathrm{~g}$ of eggs, $0.53 \mathrm{~g}$ of tofu, $0.05 \mathrm{~g}$ of spinach, $1.86 \mathrm{~g}$ of potato and $0.68 \mathrm{~g}$ of noodle.

Table 2: Optimal Solution of Food Basket 


\begin{tabular}{|c|c|c|c|c|c|c|c|c|c|c|c|c|c|c|c|c|c|}
\hline Minimize & .5 & .78 & .72 & .33 & .96 & .3 & .37 & .28 & .3 & 1.5 & .23 & .6 & .4 & 1.06 & .22 & & \\
\hline Energy & 176 & 255 & 691 & 821 & 1097 & 607 & 373 & 163 & 147 & 96.3 & 544 & 1227 & 389 & 1528 & 1608 & $>=$ & 1000 \\
\hline $\mathrm{C}_{\mathrm{x}} \mathrm{H}_{\mathrm{y}} \mathrm{O}_{\mathrm{z}}$ & 5.2 & 4.7 & 0 & .9 & 0 & 4.3 & 22.8 & 9.8 & 8.2 & 3.7 & 28.6 & 54.4 & 21.2 & 48.5 & 71.3 & $>=$ & 22 \\
\hline Fats & 1 & 3.3 & 3.6 & 15.3 & 17.8 & 8.7 & .3 & .1 & .1 & .3 & .2 & .4 & .1 & 16.5 & 4.4 & $>=$ & 5 \\
\hline Protein & 3.4 & 3.5 & 31 & 13.6 & 23.9 & 15.8 & 1.1 & .6 & .6 & 3 & 2.4 & 9 & 2.5 & 6.2 & 14.2 & $>=$ & 12 \\
\hline Vit. A & 58.8 & 29.7 & 6.3 & 218.7 & 54 & 49.8 & 19.2 & 328.2 & 4137 & 3144.3 & 0 & 0 & 3 & 6 & 18.6 & $>=$ & 300 \\
\hline Vit. C & 0 & .5 & 0 & 0 & .4 & .2 & 8.7 & 61.8 & 2.6 & 9.8 & 0 & 0 & 9.6 & 0 & 0 & $>=$ & 15 \\
\hline Vit E & 0 & .1 & .3 & 1.2 & 0 & 0 & .1 & .7 & 0 & 2.1 & 0 & .2 & 0 & 1.3 & .4 & $>=$ & 6 \\
\hline Vit. K & .1 & .2 & 2.8 & .3 & 0 & 0 & .5 & 2.6 & 9.4 & 494 & 0 & 3.4 & 2 & 4.1 & .5 & $>=$ & 30 \\
\hline $\mathrm{Ca}$ & 119 & 121 & 15 & 59 & 15 & 683 & 5 & 24 & 32 & 136 & 3 & 119 & 15 & 49 & 35 & $>=$ & 700 \\
\hline $\mathrm{Fe}$ & 0 & .1 & 1 & 2 & 1.6 & 2.7 & .3 & .1 & .9 & 3.6 & 1.5 & 3.3 & 1.1 & 3.3 & 4 & $>=$ & 7 \\
\hline $\mathrm{Mg}$ & 11 & 12 & 29 & 13 & 97 & 58 & 27 & 10 & 10 & 87 & 13 & 26 & 28 & 17 & 58 & $>=$ & 65 \\
\hline$P$ & 95 & 95 & 228 & 208 & 278 & 190 & 22 & 5 & 28 & 56 & 37 & 103 & 70 & 430 & 241 & $>=$ & 380 \\
\hline $\mathrm{K}$ & 150 & 155 & 256 & 147 & 401 & 237 & 358 & 257 & 237 & 466 & 29 & 131 & 535 & 224 & 244 & $>=$ & 2000 \\
\hline $\mathrm{Na}$ & 44 & 46 & 74 & 204 & 83 & 14 & 1 & 3 & 78 & 70 & 0 & 592 & 10 & 1052 & 21 & $>=$ & 1000 \\
\hline Solution & 0 & 0 & 0 & 4.68722 & 0 & .534497 & 0 & 0 & 0 & .4966 & 0 & 0 & 1.86132 & 0 & .677628 & & 2.6752 \\
\hline
\end{tabular}

If parents wish to add food items other than those suggested in the Model, they need to increase food expenditure that follows the value of the "Reduced" column shown in Table 3. For example, the consumption of 100 grams of milk and yoghurt will increase the costs by RM0.34 and RM0.61, respectively.

Table 3: Optimal Values of Food Items

\begin{tabular}{|c|c|c|}
\hline Food Item & Value & Reduced \\
\hline Milk, low-fat & 0 & 0.33881 \\
\hline Yoghurt-plain & 0 & 0.607823 \\
\hline Chicken & 0 & 0.457075 \\
\hline Egg & 4.68722 & 0 \\
\hline Mackerel & 0 & 0.607527 \\
\hline Tofu & 0.534497 & 0 \\
\hline Banana & 0 & 0.103634 \\
\hline Papaya & 0 & 0.045367 \\
\hline Carrot & 0 & 0.048009 \\
\hline Spinach & 0.04966 & 0 \\
\hline Rice, white & 0 & 0.208541 \\
\hline Bread, white & 0 & 0.036259 \\
\hline Potato & 1.86132 & 0 \\
\hline Biscuits plain & 0 & 0.045866 \\
\hline Noodles & 0.677628 & 0 \\
\hline
\end{tabular}

Table 4: (i) Constraints Ranging Result (ii) Optimal values of nutrient requirement for the model 


\begin{tabular}{|c|c|c|c|c|}
\hline & Surplus & Original Val & Lower Bound & Upper Bound \\
\hline Energy & 4991.108 & 1000 & -Infinity & 5991.117 \\
\hline CxHyOz & 72.47541 & 22 & -Infinity & 94.4759 \\
\hline Fats & 74.54718 & 5 & -Infinity & 79.54719 \\
\hline Protein & 74.61584 & 12 & -Infinity & 86.61588 \\
\hline Vit.A & 926.0453 & 300 & -Infinity & 1226.292 \\
\hline Vit.C & 3.462236 & 15 & -Infinity & 18.46239 \\
\hline Vit. E & 0 & 6 & 5.793162 & 6.262717 \\
\hline Vit. K & 0 & 30 & 5.44136 & 88.42194 \\
\hline $\mathrm{Ca}$ & 0 & 700 & 337.5239 & 1203.465 \\
\hline $\mathrm{Fe}$ & 8.754319 & 7 & -Infinity & 15.75437 \\
\hline $\mathrm{Mg}$ & 122.6744 & 65 & -Infinity & 187.675 \\
\hline $\mathrm{P}$ & 992.8777 & 380 & -Infinity & 1372.879 \\
\hline $\mathrm{K}$ & 0 & 2000 & 1792.426 & 8707.064 \\
\hline $\mathrm{Na}$ & 0 & 1000 & 948.642 & 1034.537 \\
\hline
\end{tabular}

\begin{tabular}{|c|c|c|}
\hline Nutrient & Original value & Level \\
\hline Energy & 1000 & 5991.117 \\
\hline CxHyOz & 22 & 94.4759 \\
\hline Fats & 5 & 79.54719 \\
\hline Protein & 12 & 86.61588 \\
\hline Vit.A & 300 & 1226.292 \\
\hline Vit.C & 15 & 18.46239 \\
\hline Vit.E & 6 & 6 \\
\hline Vit.K & 30 & 30 \\
\hline $\mathrm{Ca}$ & 700 & 700 \\
\hline $\mathrm{Fe}$ & 7 & 15.75437 \\
\hline $\mathrm{Mg}$ & 65 & 187.675 \\
\hline $\mathrm{P}$ & 380 & 1372.879 \\
\hline $\mathrm{K}$ & 2000 & 2000 \\
\hline $\mathrm{Na}$ & 1000 & 1000 \\
\hline
\end{tabular}

Table 4 shows that the value of surplus variable are as follows:

$S_{1}=4991.108, S_{2}=72.47541, S_{3}=74.54718, S_{4}=74.61584, S_{5}=926.0453, S_{6}=3.462236, S_{7}=0$, $S_{8}=0, S_{9}=0, S_{10}=8.754319, S_{11}=122.6744, S_{12}=992.8777, S_{13}=0$, and $S_{14}=0$.

Vitamin E, vitamin K, calcium, potassium and sodium have zero value for surplus variable where the resources are fully utilised. Thus, these five nutrients are binding constraints. However, a unit increase in the right-hand side of any of these nutrients will not increase food expenditure significantly.

Meanwhile, the constraints on the energy, carbohydrates, fats, protein, vitamin A, vitamin C, iron, magnesium and phosphorus are not binding in the Model since the value of the surplus is not zero. This indicates that there is an excess amount of resources which are utilised. Therefore, the "level" column as shown in Table 4 are new limitations for the constraints. These values are from the original values plus the surplus values for each constraint. 


\section{CONCLUSION AND RECOMMENDATIONS}

This study aimed to find the least cost food basket which satisfied nutritional requirements for children between two to three years old in Malaysia. The Simplex method used in this study was successful in providing a systematic tool for designing least cost nutritious food basket. The least cost diet model proposed was also significant for parents from low income households as it provides information on proper balance diet of their children with affordable food items. Furthermore, all the suggested food items such as eggs, tofu, papaya, spinach, potato and noodle are widely available in Malaysia. This study only considered children for low household income from the Malay ethnic in Malaysia; not for any other specific cultural groups or races. It would be interesting if future research works can consider the food consumption patterns of specific cultural groups or races such as Chinese, Indian or other races in Sabah and Sarawak.

\section{REFERENCES}

Briend, A., Darmon, N., Ferguson, E., \& Erhardt, J. G. (2008). Linear programming: a mathematical tool for analyzing and optimizing children's diets during the complementary feeding period. Journal of Pediatric Gastroenterology and Nutrition, 36(1), 12-22.

Eunice, M.J., Cheah, W. L., \& Lee, P. Y. (2014). Factors influencing malnutrition among young children in a rural community of Sarawak. Malaysian Journal of Nutrition, 20(2):145-164.

Ho, S. (2017). Special Report: Childhood stunting - A silent crisis in Putrajaya. The Edge Markets.

Khor, G.L., Shariff, Z.M., Sariman, S., Huang, S.L.M., \& Mohamad, M. (2015). Milk drinking patterns among Malaysian urban children of different household income status. Journal of Nutrition and Health Sciences, 1(4).

Khor, G. L., \& Sharif, Z. M. (2003). Dual forms of malnutrition in the same households in Malaysia-a case study among Malay rural households. Asia Pacific Journal of Clinical Nutrition, 12(4), 427-437.

Ministry of Health (2013). Malaysian dietary guidelines for children and adolescents summary. National Coordinating Committee on Food and Nutrition, Ministry of Health Malaysia, Putrajaya.

Schönfeldt, H. C., Gibson, N., \& Vermeulen, H. (2010). News and views: The possible impact of inflation on nutritionally vulnerable households in a developing country using South Africa as a case study. Nutrition Bulletin, 35(3), 254-267.

WHO Global Database on Child Growth and Malnutrition 14. (2011), 1994(October), 1-3.

Okubo, H., Sasaki, S., Murakami, K., Yokoyama, T., Hirota, N., Notsu, A., et al. (2015). Designing optimal food intake patterns to achieve nutritional goals for Japanese adults through the use of linear programming optimization models. Nutrition Journal, 14(1).

Temin, M., Levine, R., \& Stonisifer, S. (2010). Start with a girl: a new agenda for global health. Sciences and Technology Journal, 26(3), 33-40.

Van der Merwe, A., Krüger, H., \& Steyn, T. (2014). A diet expert system utilizing linear programming models in a rule-based inference engine. Lecture Notes in Managem 